\title{
TRAINING SENIOR HIGH SCHOOL ENGLISH TEACHERS IN DEVELOPING LISTENING ASSESSMENT
}

\author{
Nur Habibah \\ Email:nur.habibah59@gmail.com \\ MBI Amanatul Ummah \\ Mojokerto, Indonesia
}

\begin{abstract}
The ceaseless assessment ignorance, ineffective practices, even indisposition to assess listening skills among English teachers are prevalent due to the complexity of providing spoken texts, the impractical implementation, not to mention the little concern regarding teachers' assessment development. One possible way to address the problem is to improve teachers' knowledge and skills as well as encourage them to develop listening assessment through a more specific, practical and comprehensive assessment teacher training. The present study tries to train nine English fellow teachers of Senior High Schools of Amanatul Ummah in Mojokerto and Surabaya. The training focuses on the knowledge of basic concept of assessment, principles of designing a good assessment, basic types of listening assessment, tips in selecting authentic materials and the skills involving the trainee teachers' practices in developing listening assessment. Data were collected through pre and post-tests, pre-lesson notes, worksheets, reflective journal entries, and pre and post-projects. The finding shed light on the teachers' changes in knowledge, skills, and disposition to develop listening assessment during the process and afterwards.
\end{abstract}

Keywords: Teacher Training, Listening Assessment, Senior High School English Teachers.

\section{INTRODUCTION}

Assessment of students' work cannot be separated from teacher's duty as educator. It plays a powerful role in providing information about to what extent the success otherwise the failure of the teachers in administering education as well as the learners' progress, without which it is difficult to see how rational educational decisions can be made. Furthermore, In Indonesia the assessment competency becomes the core competency must be possessed by the teachers as professional. 
It includes in the aspect of pedagogic competence mentioned in Permendiknas No. 16 of 2007 about Academic Qualification Standard and Teacher Competence which equips the teachers to select various methods appropriate for the existing learning condition so that the efficient, effective, and appealing learning could be realized well and result in competent outcome. Recently, assessment of English teachers has also been taken into account as another determinant of students' graduation instead of UN result (Permendikbud No. 23 Year 2016 about Assessment Standard). The construct validity which is unsuccessfully realized in UN is hoped to be fulfilled in teacher-made tests since the administration is more flexible and adaptable in which the teachers will have more time to conduct assessment (Kubiszyn and Borich, 2003).

Unfortunately, it is hardly to say that Indonesian English teachers' competency in assessing students is near from expectation. Many studies found that most English teachers do not have comprehensive understanding in the assessment implementation of recent curriculum so that it has impacted on inappropriate assessment practices in the classroom (Khildah, 2014; Rosalina, 2015; Retnawati et.al., 2016; Sahiruddin, 2013). Some teachers' problems reported by these studies include difficulties in developing various measurement techniques, failures in designing assessment appropriately based on indicators and KD (basic competence), and misunderstanding in formulating the appropriate indicators based on KD. Furthermore, a study about assessment in primary schools in Makassar conducted by Sulfasyah (2013) also attested that the teachers' limited pedagogical practices have affected on lack efficiency in assessment. Assessment was based on these low-level skills and students were only required to achieve proficiency in the given competencies.

In the researcher's professional experiences as English teacher at Senior High School of Amanatul Ummah, Pacet, Mojokerto, the practices of summative assessment which emphasizes on reading skills, grammar, and indirect writing modes have dominated most English teachers' assessments. The complex administration, limited authentic sources, and impractical scoring lead the teachers to exclude the skills such as listening, writing, and speaking in summative assessment. As a consequence, the scores reported in the students' report do not 
represent all the skills equally. Moreover, in designing assessment most English teacher colleagues admitted that they never consider the test specifications such as KD, indicators, types of tasks, and the students' level of competence. What they know is that developing assessment from the topics provided in the textbook is enough. It is hard for them to start from KD in syllabus and then formulate appropriate test indicators from KD.

These phenomena may be attributable to the lack exposure of assessment procedure from the government and the school stakeholders. During teaching in a senior high school for about four years, there was little professional development on how to develop a good assessment against the compulsory national requirements. Notwithstanding any socialization of curriculum 2013, yet it has provided limited chance and practice in assessment breakdown. Nonetheless, the time constraint in conducting such program has made the materials less covered so that the participants got limited gain and exposure (Mangali \& Hamdan, 2015; Sahiruddin 2013). As the result, the inefficiency and inappropriate assessment conceptions as well as its practices may continuously occur among the English teachers.

The emerging problems showed that working with students' assessments is not effortless; there are many competencies beyond assessment which teachers must possess. To support an appropriate teacher-made tests as well as enhance the English teachers' competency standards, the teachers need to be better equipped and supported with a wide range of skills, content knowledge and practical experience of developing language assessment through a teacher training. Training of teachers is a more restricted kind of education which focused on specific outcomes achieved through a sequence of steps, within a specific period (Freeman, 1989:39). Crandall (2000) views teacher training as solution-oriented, with the implication that teachers are to be given specific instruction in practical techniques to cope with predictable events. Therefore, the training program is likely a good solution to help the teachers improve their individual performance of a particular area of skills and knowledge of assessment since it enables teachers to have a specific instruction in practical techniques. 
This research project was born from a desire to initiate a particular program in some planned sessions where English teachers could have specific materials about developing assessment accompanied by the real actions through activities and exercises on how to develop a good assessment. The training program will be held in Amanatul Ummah school, Pacet, Mojokerto where so many English teachers still have less experiences and lack understanding of assessment conceptions and its implementations. In addition, they have also been teaching in the same school as the researcher has. This link will enable the researcher to gain access to the schools more easily in terms of getting permission from the principal to undertake the study and inviting the teachers to participate.

For the research focus, this training will be projected in developing listening assessment. Of all English skills, listening assessment has been the most frequently ignored, least understood and least developed by most English teachers (Buck, 2001; Khilda, 2014; Miller, 2003; Nurgiyantoro, 1987; Rosalina, 2015) especially the target teachers from Amanatul Ummah. The impracticality as well as complexity of material preparation, implementation and scoring, not to mention the scarcity of authentic sources may become the focal factors. In designing listening assessment, most teachers like to use cloze test as it is simple, easy, and efortless to administer, otherwise they depend on the listening tasks provided in the textbooks which are sometimes less authentic (Azizah, 2014) and monotonous (Khilda, 2014; Rosalina, 2015).

Based on the rationales stated above, the current study is purposed to investigate: 1 ) how the teacher training contributes to the improvement of trainee teacher's knowledge in assessment and developing listening assessment, 2) how the teacher training contributes to the improvement of trainee teacher's skills in developing listening assessment, and 3) how the trainee teachers make sense of their experiences in teacher training.

By the end of the training, hopefully English trainee teachers are disposed to apply their knowledge in a more appropriate listening assessment with more various and creative formats of listening assessment instruments. On the top of that, although the training could 
not reach English teachers generally, at least the results could give a straightforward contribution to the enhancement of assessment knowledge and skills for English teachers at Amanatul Ummah Mojokerto as well as provide insights for the school principals, stakeholders, or future researchers to initiate the similar program. All in all, hopefully Indonesian English teachers' competency standards will ultimately be improved and they will be more motivated to design a qualified teacher-made test, as what is aimed by the national education goal.

\section{METHODS}

Nine English fellow teachers (2 males, 7 females) from senior high schools of Amanatul Ummah (AU) Surabaya and Mojokerto were trained. All participants shared the similar characteristics and competences which means that they come from the same school foundation and have the same problems dealing with assessing students especially listening skills. Since the trainee's domicile is not necessarily nearby their schools, the training was conducted in two batches within two meetings. Batch 1 was done in the researcher's house in Surabaya where six participants involved in. The other three participants joined batch 2 which was administered in the teacher office at MBI AU Pacet. Additional meetings were also done personally with each participant who consulted and submitted the training worksheets and projects.

The first meeting covered the knowledge of basic concept of assessment, kinds of assessment, and basic principles of language assessment, while the second meeting comprised basic types of listening assessment, KD and indicators of listening tasks, and the trainees' practices in developing listening assessment. Data were collected from pre and post-tests (20 questions with 10 multiple choice and 10 true-false form), pre-lesson notes, worksheets provided in the training module, reflective journal entries, as well as pre and post-projects (developing listening assessment). Here is the process of collecting the data: 
Habibah

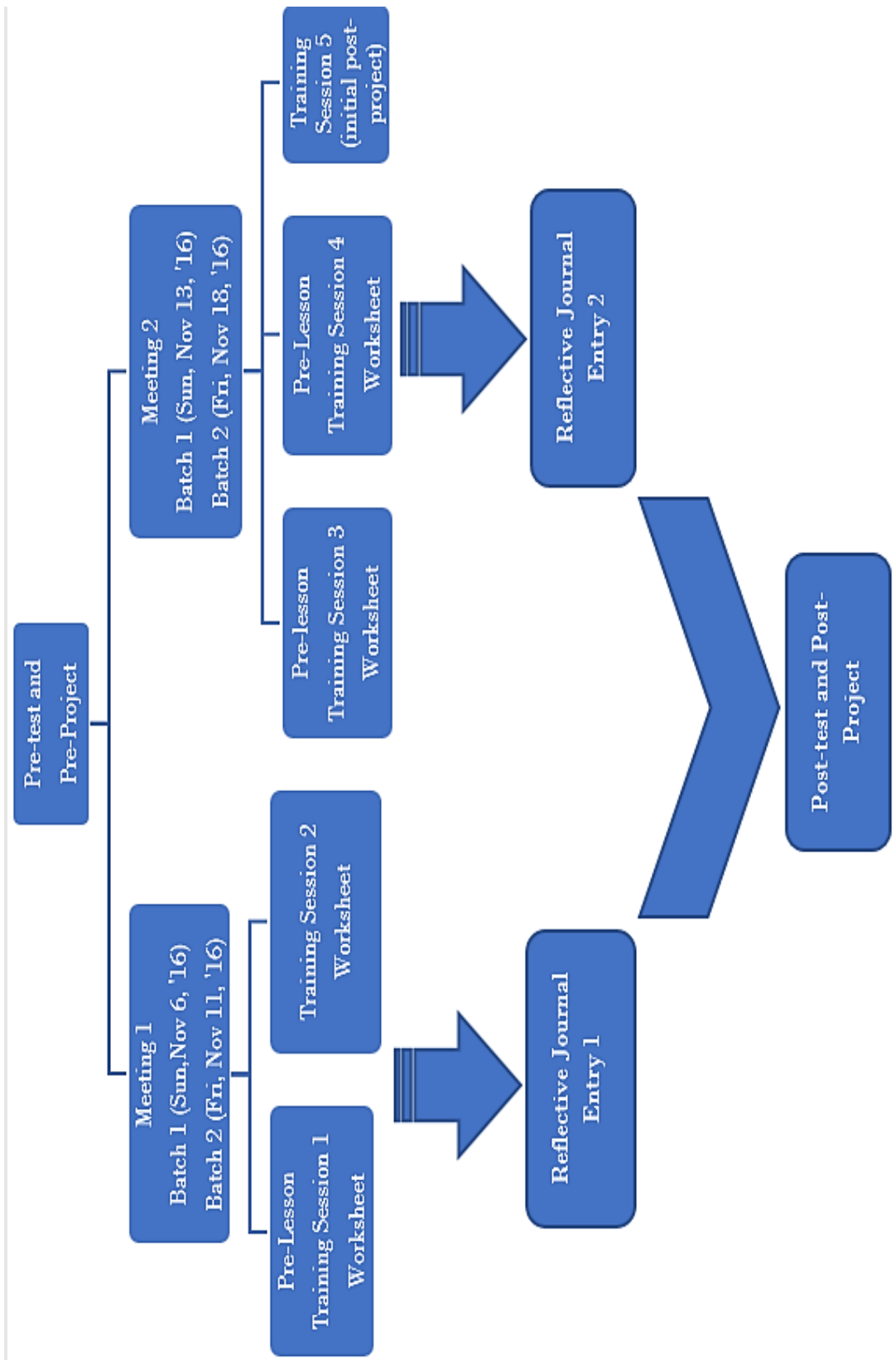

Figure 1. Data Collection Stages 
The trainees' knowledge of assessment and developing listening assessment was measured by pre and post-tests, pre-lesson notes, worksheets, and was supported by their responses in the reflective journals. The skills in developing listening assessment were investigated through trainees' performing two tasks (Pre and Post project) of developing listening assessment. Each trainee was given the different KD to develop into appropriate indicators, test-items, task types, answer key, and assessment guide. Then, the result of each task was determined by using the rubric in Appendix 1. Lastly, the trainees' making senses of the training program were analyzed from their reflective journals. The data attained were their overall perceptions in joining the training program, things they successfully learned, the difficulties (things they have perceived not successful, uncertain, or hard), and efforts needed to overcome their difficulties. They were allowed to share their emotions and perceptions during composing their reflections.

\section{FINDINGS AND DISCUSSION}

Regarding the trainee teachers' knowledge of assessment and developing listening assessment, the finding shows an improvement of the overall trainee teachers' knowledge. The most significant change appeared in the knowledge of kinds of assessment and test, followed by basic concept of assessment, basic types of listening assessment, principles of language assessment, and $\mathrm{KD} /$ indicators for listening assessment respectively. In fact, the indicator of their success was identified from the less mistakes they made when doing pre/post-test and worksheets. The challenge was higher when they had difficulty of accomplishing the task given. Thus, the findings of the worksheets and reflective journals are relevant to the pre and post-test results. The more the improvement of the knowledge in the post-test, the more the trainees' accomplishment of worksheet dealing with that knowledge, while those who had the least progress in the post-test tend to make more mistakes in their worksheets.

Secondly, the finding also proves that trainees' skills in developing listening assessment were notably improved, although two trainees' skills couldn't be determined due to no submitted data. 


\begin{tabular}{|c|c|c|c|c|}
\hline Trainee & $\begin{array}{c}\text { Pre-project } \\
\text { Skill Level }\end{array}$ & Category & $\begin{array}{c}\text { Post-project } \\
\text { Skill Level }\end{array}$ & Category \\
\hline $\mathbf{5}$ & Intermittent & 6 & Very good & 1 \\
\hline $\mathbf{4}$ & $\begin{array}{c}\text { Extremely } \\
\text { Limited }\end{array}$ & 5 & Very good & 1 \\
\hline $\mathbf{1}$ & $\begin{array}{c}\text { Intermittent } \\
\text { Extremely } \\
\text { Limited }\end{array}$ & 6 & Modest & 3 \\
\hline $\mathbf{7}$ & $\begin{array}{c}\text { Limited } \\
\text { Limited }\end{array}$ & 4 & Good & 2 \\
\hline $\mathbf{8}$ & Limited & 4 & Very good & 1 \\
\hline $\mathbf{9}$ & $\begin{array}{c}\text { Limited } \\
\mathbf{3}\end{array}$ & 4 & $\begin{array}{c}\text { Did not attempt } \\
\text { the task }\end{array}$ & 3 \\
\hline $\mathbf{6}$ & $\begin{array}{c}\text { Did not attempt } \\
\text { the task }\end{array}$ & 7 & $\begin{array}{c}\text { Did not attempt } \\
\text { the task }\end{array}$ & 7 \\
\hline
\end{tabular}

Table 1. The Progress Report of Achieved Skills (in ascending order) in Developing Listening Assessment in The Pre and Post Project

The results of pre-project initially indicate that almost all trainees didn't develop the listening assessment efficiently regarding the irrelevance between indicator and KD as well as the test items with indicators, the inappropriateness of test items due to lack reflection of assessment principles, the mainstream task types, and the incompletion of the assessment procedures. Conversely, there is a progressive change in the overall trainees' skills after being trained. The noticeable improvement is that the tasks of the post-projects are more creative and various than those of the pre-projects which were identical with fill-in-the-blanks and multiple choice selections. Despite some existing mistakes, the improvement also appears in the formulation of indicators in terms of the operational verb use, the language skills specification, and the clear context/stimulus. In addition, it is found out that the trainees' success in the post-tests and the worksheets' completion contributes to the accomplishment of the post-projects, and vice versa. 
Concerning the trainees' making senses of the training program, it is discovered that all trainees had a positive attitude towards this training even though there were two trainees also perceived both praise and disappointment. The emergent disappointment was attributable to a feeling of tiredness and workload. It is also found out that the difficulty emerged when they had to implement their understanding into practice such as evaluating some assessment scenarios with 5 basic principles, determining tasks into micro/macro listening skills, categorizing listening assessment samples into basic types of listening assessment, formulating indicators, and selecting appropriate tasks based on the indicators formulated. To counterpart their uncertainties and difficulties, they always tried to consult the trainer or other participants, reread the module, and it is evident that the listening assessment resources from the trainer has primarily helped them much in developing listening assessment.

\section{CONCLUSION AND SUGGESTIONS}

The training program has successfully contributed to the trainee teachers' knowledge and skills as well as their willingness in developing listening assessment. The most improved knowledge is of knowledge kinds of assessment, basic concept of assessment, basic types of listening assessment, basic principles of language assessment, and $\mathrm{KD} /$ indicators for listening assessment respectively. Additionally, there is also progressive change in the overall trainees' skills in developing listening assessment, although two trainees' skills couldn't be determined due to no submitted data. The noticeable improvement is that the tasks of the post-projects are more creative and various than those of the pre-projects which were identical with fill-in-the-blanks and multiple choice selections. Despite some existing mistakes, the improvement also appears in the formulation of indicators in terms of the operational verb use, the language skills specification, and the clear context/stimulus. At last, the trainees have valued such program to be sustainably conducted and the various authentic resources for listening assessment given are perceived very beneficial for their task completion. 
The program could be developed into all English skills assessment and more comprehensive aspects in assessment, not only cognitive. In addition, since there is always kaleidoscope in curriculum, the private developing program for the teachers should also be conducted sustainably in order to upgrade the teachers' knowledge and skills for the sake of teaching efficiency. The finding is also limited to see how efficiently this training impacts on the teachers' assessment competency in the real classroom, this area might become the good idea for the those who are interested in conducting the similar studies. Otherwise, the drawbacks of the study such as the training duration, lack practices, and cost can be taken into consideration.

\section{REFERENCES}

Azizah, N. (2014). Content analysis on the english textbook 'pathway to english' used by the tenth year of senior high school and its implication in teaching english. Unpublished Thesis. Sebelas Maret University.

Buck, G. 2001. Assessing Listening. New York: Cambridge University Press.

Crandall, J. (2000). Language teacher education. Annual Review of Applied Linguistics 20, 34-55. USA: Cambridge University Press.

Freeman, D. (1989). Teacher training, development, and decision making: A model of teaching and related strategies for language teacher education. TESOL Quarterly 23, 27-45.

Khildah, U.K. (2014). Listening Comprehension Assessment conducted by an English teacher in Gresik. Thesis. Language and Literature Study Program, Post Graduate of the State University of Surabaya.

Kubiszyn, T., \& Borich, G. (2003). Educational testing and measurement. USA: John Wiley and Sons. Inc.

Mangali, Z., \& Hamdan, A.R. (2015). The barriers to implementing English school based curriculum in Indonesia: Teachers perspective. International Journal for Innovation Education and Research, 3 (4). Retrieved from: www.ijier.net 
Miller, L. (2003). Developing listening skills with authentic materials. English as a Foreign Language (EFL) Assessment Continuing and Professional Studies, UMBC.

Nurgiyantoro, B. (1987). Penilaian dalam pengajaran dan sastra. Yogyakarta: BPFE.

Permendikbud about assessment standards No. 23 Year 2016

Permendiknas about Academic Qualification Standard and Teacher Competence No. 16 Year 2007

Retnawati, H., Hadi, S., \& Nugraha, A. C. (2016). Vocational High School Teachers' Difficulties in Implementing the Assessment in Curriculum 2013 in Yogyakarta Province of Indonesia. International Journal of Instruction, 9(1).

Rosalina, N.F. (2015). Listening Assessment Used by a Senior High School Teacher. Thesis. Universitas Negeri Surabaya.

Rosalina, N.F. (2015). Listening Assessment Used by a Senior High School Teacher. Thesis. Universitas Negeri Surabaya.

Sahiruddin. (2013). The implementation of the 2013 curriculum and the issues of English language teaching and learning in Indonesia. The Asian Conference on Language Learning. Official Conference Proceedings 2013. Osaka Japan.

Sulfasyah. (2013). Investigating the implementation of the Indonesian KTSP (school-based curriculum) in the teaching of writing in year two. Dissertation. Edith Cowan University Perth, Western Australia. 